\title{
Implementation of Lesson Study to Improve Basic Teaching Ability of Geography Education Students, University of Kanjuruhan Malang
}

\author{
Suwito*, Ika Meviana \\ Geography Education Study Program \\ Universitas PGRI Kanjuruhan Malang \\ Malang, Indonesia \\ *suwito@unikama.ac.id, meviana@unikama.ac.id
}

\begin{abstract}
In order to improve teaching abilities, prospective teachers must understand eight basic teaching skills, namely organizing group and individual work, explaining, questioning, reinforcement, variation, discussion guiding, class management and opening and closing skills. Lesson study is a model that is used as a teaching guide for students, because the model can develop collaborative, collegial and mutually beneficial work in learning (mutual learning). The purpose of this study was to improve the teaching ability of students of Geography Education, University of Kanjuruhan Malang using a lesson study model. This research was a classroom action research. The subjects were 80 students of Geography Education study program semester VI of the Faculty of Education in Kanjuruhan University of Malang which were selected by simple random sampling. The results showed that all teaching skills of Geography Education students were significantly improved after applying the lesson study model, from average score of 51,78 to 83,75 .
\end{abstract}

Keywords—lesson study, classroom action research

\section{INTRODUCTION}

Professional teachers are a major factor in determining the success of education and achieving learning goals. To become a professional teacher, prospective teachers must master basic teaching skills. Basic teaching skills are skills that teachers must have to transfer knowledge, skills, attitudes, and values to students in the learning process [1]. Basic teaching skills are complex and very important skills that must be mastered by teachers. In addition to teachers having to master the substance of the material field, basic teaching skills are also supporting skills for success in the learning process [2].

From the results of the observations that the author has made and during being a PPL student companion lecturer, it was found that PPL students as prospective teachers have not been able to master the basic skills of teaching practically. Thus their teaching ability still requires refresher efforts in order to respond and adapt to the demands of the developing times in order to produce quality human resources in the future. In improving the teaching abilities of prospective teachers, eight basic teaching skills must first be understood. According to Pradipta and Herminarto [3]. Theoretical mastery of basic teaching skills, it is not enough just to memorize it but must be trained and carried out through teaching training guidance. Teaching exercises are carried out in the form of teaching fellow friends in a group that is cared for by the supervisor. Given that each type of basic teaching skill is closely related to one another and applicable, it is necessary to master them through classroom training. Exercises are performed regularly and in a controlled, observable and coherent mechanism of activity.

One of the efforts to prepare the abilities of prospective teachers can be done through a process of training or learning using a model or a more simplified learning approach using lesson study learning. Many positive things in the form of functional relationships, influence, and development are obtained as a result of the application of lesson study in Geography learning. Lesson study is a model used for teaching guidance for students, because in this model collaborative, collegial and mutually beneficial work is developed in learning [4]. This theoretical fact shows that lesson study can be used to organize, train and guide students in learning activities.

Based on the results of Ismail's study [5], there was an increase in the teaching ability of the Gorontalo State University FMIP students which was seen from the PPL score that increased from before. Furthermore, Rustono [6]. In his research "Improving the Ability of Students to Implement Learning Strategies through Lesson Study" found that lesson study as a collaborative and collaborative teacher coaching model can be used as a model for tutoring by lecturers to students. In line with this, Ningsih [7]. In his research found that the average motivation, activeness and learning outcomes of students reached $82.75 \%$ of the lesson study implementation.

Lesson study learning model is a skill to organize activities in learning associated with efforts to master basic teaching skills through mentoring. Activities in the lesson study strategy 
are carried out in a series of activity cycles: Planning-DoingSeeing (Plan-Do-See). For the purposes of mentoring students in mastering 8 basic teaching skills, these three activities are preceded by conditioning.

\section{MeTHODS}

This research uses classroom action research. The population in this study were all students of the Geography Education Study Program, Kanjuruhan University of Malang. The sample used in this study were 80 students of Geography Education, University of Kanjuruhan Malang selected from simple random sampling. The instrument in this study was the observation sheet for the assessment of basic teaching skills. Data collection techniques using a Likert scale with an assessment score of 1-4. The scoring guidelines for students' basic teaching skills using the lesson study model are as in table 1 .

TABLE I. GUIDELINES FOR SCORING BASIC TEACHING SKILLS USING LESSON STUDY

\begin{tabular}{|l|l|}
\hline \multicolumn{1}{|c|}{ Score } & \multicolumn{1}{c|}{ Criteria } \\
\hline 1 & Very less \\
\hline 2 & Less \\
\hline 3 & Good \\
\hline 4 & Very good \\
\hline
\end{tabular}

The technique used is the data analysis technique according to Miles and Huberman in Sugiyono, which explains that activities in qualitative data analysis are carried out continuously until it is complete so that the data is saturated. There are three phases of activities to be carried out, namely: (1) Analysing all the data collected; (2) Reducing data using formulas; (3) Presenting and concluding data.

To do the lesson study, students were divided into group of five. Every student was conducted in form of small group 4 phase, as follows.

\section{A. Conditioning}

In this stage, students understand the material to be taught in the classroom by gathering all information about the material. After understanding the material, students condition how to teach the material according to the 8 components of known basic skills.

\section{B. Planning}

At this planning stage, a discussion was held involving the research team with students who were willing to take part in the Lesson Study activities in the Microteaching course. Some of the problems that were revealed were the ability of students as teaching practice (microteaching) to not understand the concept of basic skills that must be possessed by teachers when learning.

\section{Implementation}

The stage is where each student practiced to teach based on the plan. In this stage, the other students in the group observed the flow of teaching as well as the student's activity.

\section{Reflection}

Reflection is carried out so that students / models recall mistakes that have been made by making improvements in the future. This reflection is carried out by the research team and students as a model, carried out at the end of the lesson, including through discussion, question and answer, conveying impressions and messages, writing journals, giving comments to each other's work, and notes in a diary. This activity is in accordance with the opinion of Khusniati [8] which states that reflection in learning can foster the ability to think logically and critically, know one's own strengths and weaknesses and respect the opinions of others.

\section{RESUlts AND Discussions}

The results of the analysis of the value of the teaching ability of Geography students using lesson study are presented as follows:

TABLE II. The VAlue of THE TEACHING ABILITY OF GeOGRAPHY STUDENTS USING LESSON STUDY

\begin{tabular}{|l|l|l|}
\hline \multicolumn{1}{|c|}{ Basic teaching skills } & Cycle I & Cycle II \\
\hline Organizing group and individual work skills & 55.81 & 80.74 \\
\hline Explaining skills & 43.30 & 79.05 \\
\hline Questioning skills & 50.02 & 88.45 \\
\hline Reinforcement skills & 58.23 & 79.09 \\
\hline Variation skills & 52.72 & 92.03 \\
\hline Discussion guiding skills & 40.03 & 74.09 \\
\hline Class management skills & 52.08 & 83.31 \\
\hline Opening and closing skills & 62.02 & 93.21 \\
\hline AVERAGE & & $\mathbf{8 3 . 7 5}$ \\
\hline
\end{tabular}

Based on table 2 above, it can be stated that there has been a significant increase in student teaching practice in each of the components of basic teaching skills that must be possessed by students as prospective teachers.

It can be seen that in the first cycle, the student's opening skills component was 55.81 on average and in the second cycle there was an increase of 80.74 . This is because in the first cycle there were student's unpreparedness in applying the concept of the eight basic skills and they had not yet examined the relationship between the concepts and the material presented.

Students experienced difficulties in the skills component as a focus of practice, students do not understand the concept of the material to be taught so that there is ambiguity during the learning process. So at the planning stage, improvements were made and continued at the implementation stage, students could focus more and concentrate on learning. This is in 
accordance with the objectives of the lesson study learning model to improve and deepen teachers' understanding of the learning material, the scope and sequence of the material being taught [9].

\section{CONCLUSION}

Based on the data obtained, it can be concluded that the application of lesson study learning models can improve the teaching ability of Geography students at Kanjuruhan University Malang. To improve basic teaching skills, both teachers and lecturers can apply the lesson study learning model to students.

\section{REFERENCES}

[1] M. Mulyatun, "Analysis of Basic Teaching Skills for Chemistry Teacher Candidate Students (a study on the practical field experience of Chemistry Tadris Students)," Phenomenon Journal, vol. 1, no. 4, pp. 7990, 2014.

[2] S. Siswanto, "Mastery Level of Basic Teaching Skills for Study Program Students Accounting Education, Faculty of Social and Economic
Sciences, Yogyakarta State University," Indonesian Journal of Economic Sciences, vol. VIII, no. 2, pp. 41-51, 2010.

[3] A.W. Pradipta and S. Herminarto, "Implementation of PBL to Increase Motivation, Creativity and Concept Understanding," Journal of Educational Technology Innovation, vol. 1, no. 2, pp. 32-48, 2010.

[4] D. Rahmawati, "Increasing Professional Competence of Teacher Candidates through Lesson Study," Axiom., vol. 1, no. 3, pp. 2833 2014.

[5] S. Ismail, Establishing the Mastery of Basic Teaching Skills for Students in Mathematics Education Study Program Participants of PPL-1 in Teaching Training Guidance through Lesson Study. Article. Gorontalo State University, 2014.

[6] W.S. Rustono, "Improving Students' Ability to Implement Learning Strategies through Lesson Study in Elementary Schools," Journal of Basic Education, vol. 8, no., pp. 21-32, 2008.

[7] S.C. Ningsih, "Implementation of Lesson Study in an Effort to Increase Student Motivation and Learning Outcomes," Proceedings, 2008.

[8] M. Khusniati, "Character Education through Natural Science Learning," Journal of Indonesian Science Education (JPII), vol. 1, no. 2, 2012.

[9] A. Rian and C. Umi, "Implementation of Lesson Study Based on Subject Teacher Deliberation (MGMP) towards Increasing the Professional Competence of Middle School Civics Teachers in Ogan Ilir Regency," Forum Journal Social, vol. V, no. 2, 2012. 